
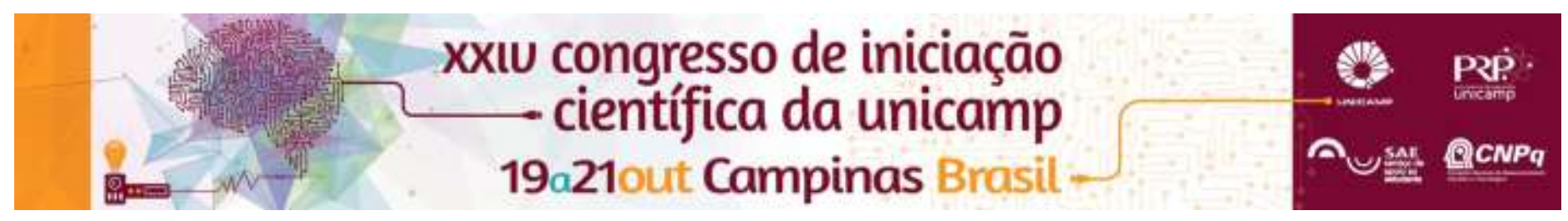

\title{
Contaminantes emergentes no Ribeirão das Pedras: o impacto desde a nascente até a sua foz
}

\author{
Natália C. Fernandes*, Raphael D. Acayaba, Cassiana C. Montagner
}

Laboratório de Química Ambiental, Instituto de Química, UNICAMP.

*fnatalia.rodrigues@outlook.com.br

\section{Resumo}

O Ribeirão das Pedras possui $10 \mathrm{~km}$ desde a sua nascente (P1) até a sua foz (P3) no Ribeirão Anhumas, cruza um trecho predominantemente urbano na cidade de Campinas, sendo que a metade do seu curso está localizada no centro de Barão Geraldo (P2). O objetivo deste trabalho foi estudar esse corpo hídrico com vistas para os contaminantes emergentes, empregando a cafeína como traçador de contaminação por esgoto doméstico. Os resultados mostraram um aumento na concentração de cafeína e dos parâmetros físico-químicos medidos no primeiro trecho do ribeirão, mantendo-se constante até a sua foz.

\section{Palavras-chave:}

Água superficial, esgoto doméstico, cafeína.

\section{Introdução}

O Ribeirão das Pedras é um ribeirão com cerca de 10 km de extensão, seu percurso está divido entre um trecho urbanizado de Campinas e o centro do distrito de Barão Geraldo; é um rio relativamente curto que não recebe nenhum afluente ao longo de seu curso. O objetivo deste trabalho foi fazer uma avaliação detalhada da qualidade da água com a intenção de identificar se há presença de contaminantes emergentes: cafeína, bisfenol A, drogas ilícitas, fármacos, hormônios e agrotóxicos. Para isto, empregou-se extração em fase sólida (SPE) como preparo de amostras e análise por Cromatografia Líquida (LC) acoplada à espectrometria de massas em triplo quadrupolo [MS/MS(QqQ)] com ionização por electrospray (ESI).

\section{Resultados e Discussão}

Foi realizada uma coleta amostral no dia 20/05/2016 (final do período de chuvas) a fim de avaliar a presença de contaminantes emergentes no ribeirão. As amostras foram coletadas em três pontos - (P1) a nascente, (P2) ponte localizada ao lado do colégio Rio Branco $(R B)$ e (P3) foz, localizada no Hotel Barão Geraldo.

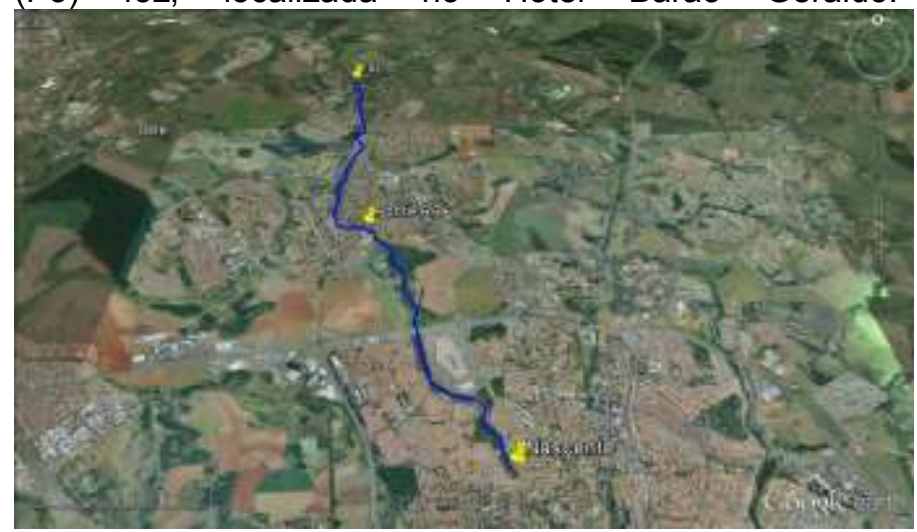

Figura 1. O mapa ilustra parte da cidade de Campinas e do distrito de Barão Geraldo, por onde passa o Ribeirão das Pedras (identificado em azul). Em amarelo foram marcados os pontos de coleta (o ponto mais acima no mapa é a foz e abaixo, a nascente).
Dos três contaminantes investigados até o momento, todos foram detectados; a cafeína utilizada como traçador, foi encontrada em todas as amostras, inclusive na nascente.

Tabela 1. Propriedades físico-químicas determinadas nos respectivos pontos amostrais.

\begin{tabular}{cccc}
\hline Ponto Amostral & Nascente & Ponte RB & Foz \\
\hline pH & 5,7 & 7,5 & 7,8 \\
Condutividade (uS) & 153 & 273 & 169 \\
T ( $\left.{ }^{\circ} \mathbf{C}\right)$ & 24 & 19 & 21 \\
OD & 8,7 & 8,2 & 6,2 \\
TOC (mg/L) & 1,35 & 5,05 & 3,99 \\
Cafeína (ng/L) & 14 & 313 & 288 \\
\hline
\end{tabular}

De acordo com os resultados obtidos, observou-se um alto valor de condutividade e a presença de cafeína na nascente, indicando um provável cenário de contaminação. Outro resultado que pode ser destacado é uma maior quantidade de cafeína no $\mathrm{P} 2$ com relação à foz; esse resultado pode ser devido a um possível aporte de esgoto doméstico no corpo d'água estudado. A determinação dos outros contaminantes emergentes está sendo finalizada.

\section{Conclusão}

Os resultados mostraram possíveis aportes de esgoto doméstico, predominantemente no primeiro trecho estudado. As análises de outros compostos oriundos do esgoto, aliadas a análises de agrotóxicos complementará o estudo quanto ao grau de contaminação real do Ribeirão das Pedras.

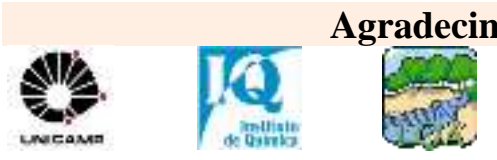

FAPESP 2014/24740-6 